\title{
Kardiomiopatia takotsubo u dziecka - opis przypadku
}

\author{
Takotsubo cardiomyopathy in a child - case report
}

\author{
Beata Kutek, Jacek Kusa \\ Katedra i Klinika Kardiologii Dziecięcej Śląskiego Uniwersytetu Medycznego w Katowicach \\ Oddział Kardiologii Dziecięcej Wojewódzkiego Szpitala Specjalistycznego we Wrocławiu
}

\section{Streszczenie}

W artykule przedstawiono przypadek chłopca w wieku 14 lat, który został przyjęty na oddział kardiologii dziecięcej z objawami ostrego zespołu wieńcowego. Na podstawie przeprowadzonej diagnostyki rozpoznano kardiomiopatię takotsubo. Objawy choroby wystąpiły po urazie klatki piersiowej, do którego doszło podczas zawodów sportowych (pacjent intensywnie trenuje taekwondo). Chłopiec przeżywał bardzo silny stres związany z rywalizacją. W wykonanej angiotomografii komputerowej wykluczono obecność patologii wieńcowych, natomiast w badaniu echokardiograficznym stwierdzono typowy obraz towarzyszący kardiomiopatii takotsubo. Podczas hospitalizacji obserwowano szybką poprawę stanu ogólnego z normalizacją geometrii lewej komory i poprawą kurczliwości. W rodzimej literaturze autorzy nie znaleźli opisu kardiomiopatii takotsubo w populacji dziecięcej.

Słowa kluczowe: kardiomiopatia takotsubo, ostry zespół wieńcowy, katecholaminy

Folia Cardiologica 2018; 13, 3: 264-268

\section{Wstęp}

Zespół takotsubo po raz pierwszy opisał Hikaru Sato w Japonii w 1990 roku [1]. Przedstawił przypadek pacjenta z klinicznym i elektrokardiograficznym obrazem ostrego zawału serca, u którego w wentykulografii zaobserwowano szczególny końcowoskurczowy kształt lewej komory z dyskinetycznym poszerzeniem koniuszka i przewężeniem w środkowej części komory [1]. Od tej pory jednostce tej nadawano różne nazwy: kardiomiopatia takotsubo, kardiomiopatia stresowa, zespół balotowania lewej komory, „zespół złamanego serca”.

Do rozpoznania choroby konieczne jest spełnienie wszystkich 4 kryteriów Mayo Clinic [2] (tab. 1). Cechą tej choroby jest czasowy związek z dużym stresem - emocjonalnym lub fizycznym. Zespół takotsubo najczęściej opisuje się u kobiet w wieku 60-70 lat [3].
Etiologia zespołu takotsubo nie jest do końca poznana. W wielu opracowaniach tłumaczy się ją skurczem tętnicy wieńcowej w odcinku nasierdziowym [4], w innych postuluje się mechanizmy bezpośredniego uszkodzenia kardiomiocytów w wyniku nasilonej aktywacji współczulnej [5]. Najlepiej udowodnioną teorią jest koncepcja mówiąca o skurczu lub dysfunkcji naczyń mikrokrążenia wieńcowego indukowanego wyrzutem katecholamin [5]. Znaczenie wyrzutu katecholamin potwierdza opis przypadku wtórnego zespołu takotsubo u 59-letniego mężczyzny z pheochromocytoma [6]. Niekiedy sugeruje się genetyczną skłonność, o czym może świadczyć wystąpienie tego zespołu u rodzeństwa [7].

\section{Opis przypadku}

Na oddział kardiologii dziecięcej przyjęto chłopca w wieku 14 lat z podejrzeniem ostrego zespołu wieńcowego.

Adres do korespondencji: dr hab. n. med. Jacek Kusa, Katedra i Klinika Kardiologii Dziecięcej, Śląski Uniwersytet Medyczny w Katowicach, ul. Medyków 16, 40-752 Katowice, tel. 3220718 55, e-mail: jkusa@poczta.onet.pl 
Tabela 1. Kryteria rozpoznania* kardiomiopatii takotsubo według Mayo Clinic

Przemijająca hipokineza, akineza lub dyskineza środkowych segmentów lewej komory z zajęciem koniuszka lub bez zajęcia; regionalne zaburzenia kurczliwości zasięgiem wykraczają poza obszar ukrwienia jednej tętnicy wieńcowej

Nieobecność choroby wieńcowej lub angiograficznych dowodów obecności pękniętej blaszki miażdżycowej

Nowe nieprawidłowości w EKG (uniesienie odcinka ST i/lub odwrócone załamka T) lub podwyższona aktywność troponin sercowych

Wykluczenie: przebytego niedawno urazu głowy, krwawienia wewnątrzczaszkowego, guza chromochłonnego, zapalenia mięśnia sercowego, kardiomiopatii przerostowej

*Do rozpoznania choroby konieczne jest spełnienie wszystkich 4 kryteriów; EKG - elektrokardiografia

Bezpośrednim powodem zgłoszenia się do szpitala było pojawienie się duszności z silnym spoczynkowym bólem zamostkowym o charakterze uciskowym trwającym kilka godzin. Objawom tym towarzyszyła gorączka $38,5^{\circ} \mathrm{C}$. W dniu przyjęcia pacjent doznał urazu klatki piersiowej. Chłopiec od kilku lat intensywnie ćwiczy taekwondo, osiąga sukcesy na szczeblu krajowym. Przy przyjęciu stan ogólny chłopca był średni, w badaniu fizykalnym ciśnienie tętnicze było podwyższone do 135/88 mm Hg, tachykardia zatokowa wynosiła $120 / \mathrm{min}$. W spoczynkowym badaniu elektrokardiograficznym (EKG) stwierdzono rytm zatokowy, poziome uniesienie odcinka ST-T powyżej $1 \mathrm{~mm}$ w odprowadzeniach II, III, aVF, V2-V6, obniżenie poziome ST-T o $1 \mathrm{~mm}$ w aVR (ryc. 1). W badaniu echokardiograficznym uwidoczniono: hiperkinezę podstawnej części lewej komory, przewężenie w środkowym odcinku oraz "balonowate” dyskinetyczne uwypuklenie koniuszka z echogeniczną krwią w jej obrębie (ryc. 2). W wykonanej angiotomografii tętnic wieńcowych obserwowano ich prawidłowy obraz, bez anomalii przebiegu i przewężeń (ryc. 3).

Podczas pobytu na oddziale wzrastały następujące wskaźniki biochemiczne:

- stężenia troponiny l: od 1,94 do 30,92 ng/ml;

- stężenie kinazy kreatynowej (CK, creatine kinase): od 423 do $1382 \mathrm{j} . / \mathrm{l}$;

- stężenia izoenzymu sercowego kinazy kreatynowej (CK-MB, creatine kinase myocardial bound): do $146 \mathrm{j} . /$;

- stężenie dehydrogenazy mleczanowej (LDH, lactate dehydrogenase): od 199 do 399 j./l;

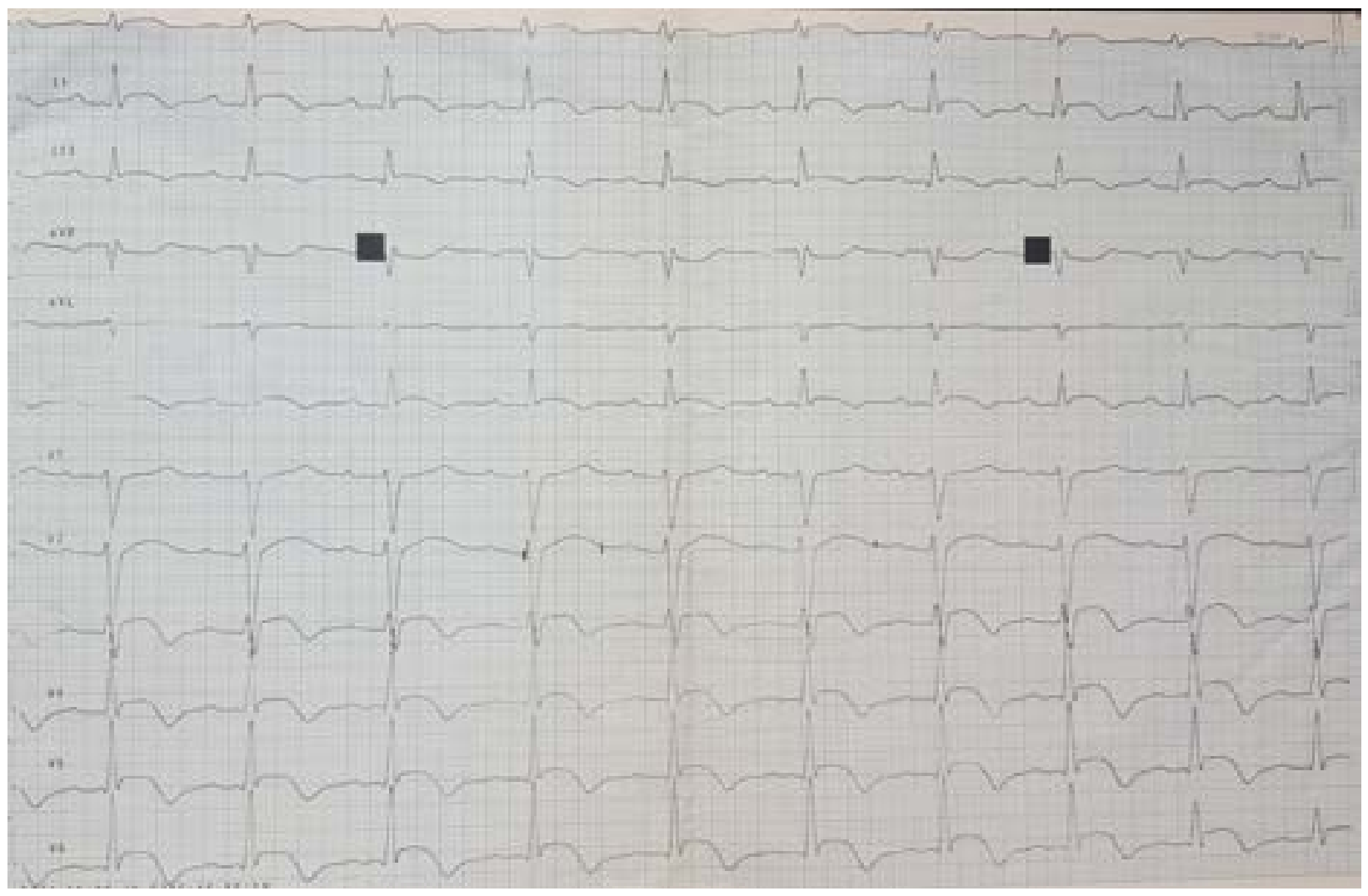

Rycina 1. Zapis elektrokardiograficzny wykonany przy przyjęciu do szpitala (prędkość przesuwu papieru $50 \mathrm{~mm} / \mathrm{s}$ ) 


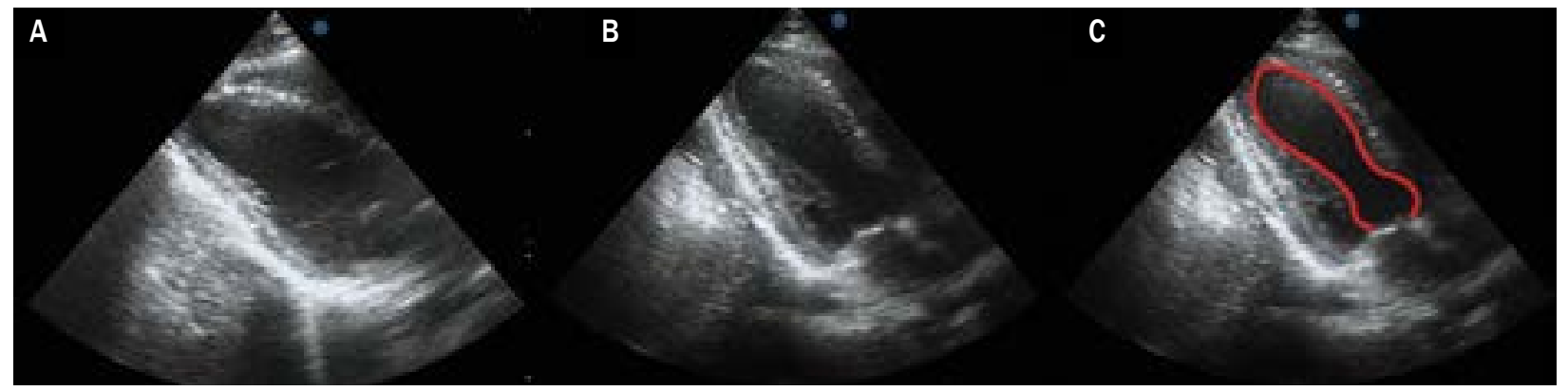

Rycina 2A-C. Badanie echokardiograficzne: A. Obraz lewej komory w rozkurczu; B. Obraz lewej komory w skurczu - „balonowate”, dyskinetyczne uwypuklenie koniuszka lewej komory z przewężeniem w środkowym odcinku; C. Obraz lewej komory w skurczu - obrysowane granice wsierdzia

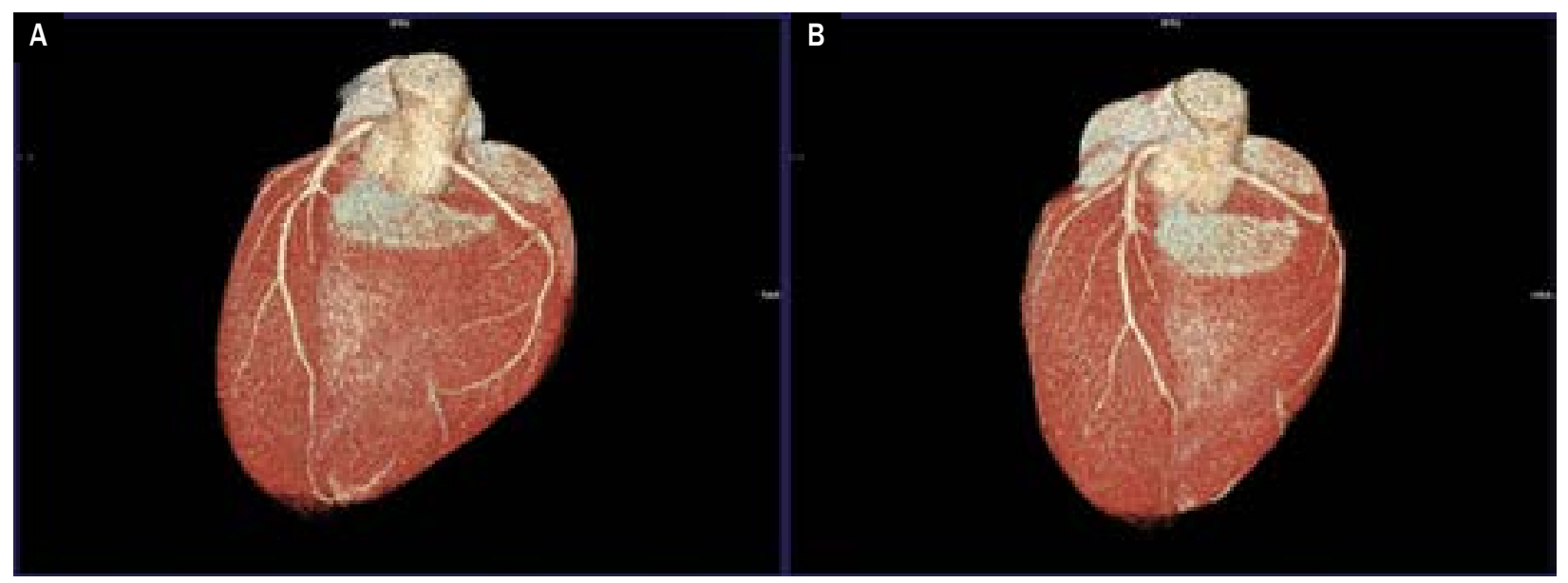

Rycina 3A, B. Badanie agiotomografii komputerowej (rekonstrukcja) - prawidłowy obraz odejścia tętnic wieńcowych, bez anomalii i przewężeń

- stężenie białka C-reaktywnego ([CRP, C-reactive protein] marker stanu zapalnego): do 176,35 mg/l.

W 24-godzinnej zbiórce moczu oznaczono katecholaminy, których wartości były znacznie podwyższone:

- noradrenalina - 0,274 $\mu \mathrm{g} / \mathrm{mg}$ kreatyniny (norma 0,004-0,105);

- adrenalina - 0,157 $\mu \mathrm{g} / \mathrm{mg}$ kreatyniny (norma 0,003$-0,058)$;

- dopamina - 3,087 $\mu \mathrm{g} / \mathrm{mg}$ kreatyniny (norma 0,12$-0,45)$.

W 7. dobie hospitalizacji wykonano rezonans magnetyczny serca, w którym stwierdzono prawidłową wielkość i kurczliwość mięśnia lewej komory oraz wykluczono zapalenie mięśnia sercowego. Wyniki badań wirusologicznych nie potwierdziły tła wirusowego. W 24-godzinnym monitorowaniu EKG zarejestrowano dominujący rytm zatokowy z tendencją do tachykardii zatokowej oraz pojedyncze skurcze dodatkowe nadkomorowe. U chorego zastosowano leczenie przeciwpłytkowe kwasem acetylosalicylowym oraz beta-adrenolityczne z zastosowaniem metoprololu.

Trzeciego dnia hospitalizacji kurczliwość globalna serca wróciła do normy, obserwowano obniżenia wartości markerów sercowych, a następnie ich normalizację w 13. dobie. W regularnie wykonywanych badaniach EKG wykazano regresję uniesienia odcinka ST-T oraz wykształcenie się początkowo ujemnych, a następnie dodatnio-ujemnych załamków T w odprowadzeniach przedsercowych V2-V6, które utrzymywały się do dnia wypisu. Pacjenta wypisano do domu w dobrym stanie ogólnym.

Podczas 6-letniej obserwacji nie nastąpił nawrót choroby. W badaniu echokardiograficznym utrzymywała się prawidłowa kurczliwość serca, zmiany w zapisie EKG wycofały się w 12. miesiącu obserwacji.

\section{Dyskusja}

Podstawą rozpoznania zespołu takotsubo u opisanego pacjenta było spełnienie wszystkich 4 kryteriów zaproponowanych przez Mayo Clinic [2]. Według wiedzy autorów jest to pierwszy taki przypadek opisany w populacji dziecięcej w Polsce.

Przypadek ten potwierdza zależność czasową między stresem fizycznym i psychicznym, który towarzyszył urazowi klatki piersiowej i współzawodnictwu, a wystąpieniem 
objawów zespołu. W badaniu echokardiograficznym zobrazowano typowe regionalne zaburzenia kurczliwości lewej komory z zajęciem koniuszka wykraczającym poza obszar ukrwienia jednej tętnicy wieńcowej.

Ewolucja zmian w badaniu elektrokardiograficznym uniesienie odcinka ST-T, odwrócenie załamka T i następcza regresja zmian - odpowiadała przyjętym kryteriom rozpoznania i utrzymywała się najdłużej spośród stwierdzonych odchyleń - aż do 12. miesiąca [8].

Obserwowany u pacjenta znamienny wzrost wartości amin katecholowych potwierdza najbardziej prawdopodobną hipoteze ich wpływu na lokalne receptory w mięśniu sercowym, co wywołało obkurczenie naczyń mikrokrążenia i tym samym pogorszenie ukrwienia serca. Opisana patogeneza została potwierdzona na podstawie badań obrazowych oceniających perfuzję mięśnia sercowego przy użyciu tomografii emisyjnej pojedynczego fotonu (SPECT, single-photon emission tomography) oraz pozytonowej tomografii emisyjnej (PET, positron emission tomography) [9].

Autorzy jednego z badań, w którym podawano szczurom duże dawki adrenaliny i noradrenaliny, udowodnili, że to głównie adrenalina odpowiada za opisywane odwracalne zmiany w obrębie koniuszka serca. Wybiórczość działania na koniuszek tłumaczyli szczególną wrażliwością tych struktur jako miejsca o największym zagęszczeniu receptorów adrenergicznych [8]. Obserwowany istotny wzrost stężenia enzymów martwicy serca u opisywanego pacjenta potwierdza również inne hipotezy etiopatogenezy tej choroby, według których na bezpośrednie uszkodzenie kardiomiocytów wpływa nadmiar katecholamin wskutek przeładowania wapniem siateczki śródplazmatycznej miocytów [10]. Wielu autorów zakłada również hipotezę występowania niedokrwienia mięśnia sercowego wskutek skurczu nasierdziowych odcinków tętnic wieńcowych wywołanego działaniem endogennych katecholamin [4]. Biorąc pod uwage tę hipoteze, autorzy niniejszej pracy wykonali u chłopca angiotomografię naczyń wieńcowych, która wykazała ich prawidłową budowę i funkcję.

\section{Podsumowanie}

Kardiomiopatia takotsubo jest rzadką chorobą, incydentalnie występującą w populacji dzieci i młodzieży. Jednak ze względu na postępujące zmiany cywilizacyjne, związane głównie z rosnącą rywalizacją i stresem, częstość jej występowania najpewniej będzie się zwiększała również w tej populacji.

\section{Konflikt interesów}

Autorzy nie zgłaszają konfliktu interesów.

\section{Abstract}

A case of a 14-year-old boy admitted to a paediatric cardiology ward with symptoms of an acute coronary syndrome is presented. Diagnostics indicated takotsubo cardiomyopathy. The symptoms occurred after the chest injury that had happened during a sports event (the patient trains taekwondo intensively). The boy was under extreme stress related to competition. Computed angiotomography ruled out coronary pathologies, while echocardiography showed typical signs of takotsubo cardiomyopathy. During hospitalisation, the patient's general condition got better fast, with the left ventricle geometry becoming normalised and cardiac contractility improving. No descriptions of takotsubo cardiomyopathy have been found in peadiatric population in Polish literature.

Key words: takotsubo cardiomyopathy, acute coronary syndrome, catecholamines

Folia Cardiologica 2018; 13, 3: 264-268

\section{Piśmiennictwo}

1. Sato H, Tateishi H, Uchida T. Tako-tsubo-like left ventricular dysfunction due to multivessel coronary spasm. In: Kodama K, Haze $\mathrm{K}$, Hori $M$, red. Clinical aspect of myocardial injury: from ischemia to heart failure. Kagakuhyoronsha Publishing, Tokyo 1990: 56-64.

2. Madhavan M, Prasad A. Proposed Mayo Clinic criteria for the diagnosis of tako-tsubo cardiomyopathy and long-term prognosis. Herz. 2010; 35(4): 240-243, doi: 10.1007/s00059-010-3339-x, indexed in Pubmed: 20582391.
3. Deshmukh A, Kumar G, Pant S, et al. Prevalence of takotsubo cardiomyopathy in the United States. Am Heart J. 2012; 164(1): 66-71.e1, doi: 10.1016/j.ahj.2012.03.020, indexed in Pubmed: 22795284.

4. Akashi YJ, Goldstein DS, Barbaro G, et al. Takotsubo cardiomyopathy: a new form of acute, reversible heart failure. Circulation. 2008; 118(25): 2754-2762, doi: 10.1161/CIRCULATIONAHA.108.767012, indexed in Pubmed: 19106400. 
5. Lyon AR, Rees PSC, Prasad S, et al. Stress (takotsubo) cardiomyopathy - a novel pathophysiological hypothesis to explain catecholamine-induced acute myocardial stunning. Nat Clin Pract Cardiovasc Med. 2008; 5(1): 22-29, doi: 10.1038/ncpcardio1066, indexed in Pubmed: 18094670.

6. Takeno Y, Eno S, Hondo T, et al. [Pheochromocytoma with reversal of tako-tsubo-like transient left ventricular dysfunction: a case report]. J Cardiol. 2004; 43(6): 281-287, indexed in Pubmed: 15242078.

7. Ikutomi M, Yamasaki M, Matsusita M, et al. Takotsubo cardiomyopathy in siblings. Heart Vessels. 2014; 29(1): 119-122, doi: 10.1007/ /s00380-013-0345-y, indexed in Pubmed: 23563753.
8. Dib C, Asirvatham S, Elesber A, et al. Clinical correlates and prognostic significance of electrocardiographic abnormalities in apical ballooning syndrome (Takotsubo/stress-induced cardiomyopathy). Am Heart J. 2009; 157(5): 933-938, doi: 10.1016/j.ahj.2008.12.023, indexed in Pubmed: 19376324.

9. Kurisu S, Inoue I, Kawagoe T, et al. Myocardial perfusion and fatty acid metabolism in patients with tako-tsubo-like left ventricula dysfunction. J Am Coll Cardiol. 2003; 41(5): 743-748, indexed in Pubmed: 12628716.

10. Mann DL, Kent RL, Parsons B, et al. Adrenergic effects on the biology of the adult mammalian cardiocyte. Circulation. 1992; 85(2): 790-804, indexed in Pubmed: 1370925. 